\title{
Sport participation of the elderly - the role of gender, age, and social class
}

\author{
Ulrike Tischer • Ilse Hartmann-Tews • \\ Claudia Combrink
}

Received: 17 January 2011 / Accepted: 24 August 2011 / Published online: 8 September 2011

(C) European Group for Research into Elderly and Physical Activity (EGREPA) 2011

\begin{abstract}
The article provides an overview of the results of cross-sectional and longitudinal data sets concerning sport participation of the elderly in Germany with a focus on correlations of sport participation with gender, age, and social class. A tabular overview lists the most central studies with their study design and publications from 2000 onwards. Findings regarding the motivations for sport participation of the elderly, the types of sport which are done, and the preferred settings are summarized. Eventually a conclusion is given about "what we know and what we don't know."
\end{abstract}

Keywords Sport participation · Age · Participation rates · Gender $\cdot$ Social stratification $\cdot$ Motivation

\section{Introduction}

Two social trends, which foster an academic interest towards sport of the elderly, are to be found over the past decades: On the one hand, we observe a demographic development towards an "ageing society" and on the other hand a trend of "sportification" of our society. The concept of an ageing society refers to a growing amount of elderly people and the related social, economic, and political consequences. The notion of a sportification of society refers to a growing number of people that have become involved in sport activities over the past decades and to the related diversification of activities and settings. Fifty years

U. Tischer $(\varangle) \cdot$ I. Hartmann-Tews $\cdot$ C. Combrink Institute of Sport Sociology, Department of Gender Studies, German Sport University Cologne,

Cologne, Germany

e-mail: tischer@dshs-koeln.de ago doing sports was a domain of young men of middle and upper classes. In Germany sports clubs were the central organizations that met their interests in physical performance and competition. Nowadays sports are widespread leisure activities including a diverse range of peopleyoung and elder people, men and women, people from the lower and upper classes, and people with different ethnic and migrational backgrounds. At the same time, the forms of sports and the settings to do sorts became more diversified - sport clubs, private enterprises, public institutions, and public spaces increased [20, 27]. It seems that elderly people are part of this sportification process as there has been a growing number of elderly people who are a member in a sports club or in a commercial sport setting.

With respect to this development, this literature review addresses the following questions: which sociodemographic profiles do physically active ${ }^{1}$ elderly people have? Are there differences in participation with regard to gender, age, and social class? Which motivations do elderly people have to do sports and which types of activities and settings do they prefer? It is of academic interest and political relevance to have a sound knowledge about the potential influence of social factors like gender, age, and social class on sport participation of the elderly.

There is a variety of surveys concerning various aspects of a healthy lifestyle including information about sport activities of the elderly. However, the surveys are based on different and heterogeneous study designs as regards the representativity of the sample, the age groups, the questions asked, the answers provided, the operationalisation of what is meant by "doing sport," etc. These difficulties are well known in the academic literature on empirical methods in

\footnotetext{
${ }^{1}$ We will use the term, physically active persons in this article in the sense that the persons are involved in physical exercises and sports.
} 
general and of comparative analysis in particular. Against this methodological background, a comparison of surveys on sports participation of elderly people is a challenge that becomes even bigger in an internationally comparative perspective [28]. Against this background the review focuses on studies in Germany and on studies on sport activity of the elderly, thus going beyond general physical activity, which includes daily life routines like gardening, household work, or transport activities.

The review focuses on research in Germany because a national review on a rather new topic provides a more valid overview and results as an international one. This derives from the fact that an international comparison of data sets has to consider different cultures of movement, physical exercise and sport, different connotations of the wordings used in the surveys (sport participation, physical exercise and sport, etc.), and sociocultural variations of ageing (e.g. differences in life expectancy) and of an ageing society (social welfare and health system). ${ }^{2}$

The review is structured in five parts: (1) the reference surveys and data sets are introduced, (2) results of crosssectional data sets concerning sport participation of the elderly are summarized, (3) findings of longitudinal studies are presented which describe sport participation in a lifecourse perspective, (4) data on motivations and attitudes towards ageing and sport of the elderly are reviewed, and (5) a summary about "what we know and what we don't know" concludes the review.

\section{Surveys and publications on sport participation of elderly people in Germany}

The article provides an overview of the empirical data on sport participation of the elderly with a focus on social factors, i.e., gender, age (categories), and social stratification. In order to do so, it is necessary to consult a broad range of surveys which have integrated at least some questions and data on the topic of physical activities and sports, as there are only very few surveys solely focusing on sport of the elderly. On the one hand, data are derived from representative general population surveys in Germany [e.g., socioeconomic panel (SOEP), cf. Table 1] or surveys focusing on health and health-related behavior of the population (e.g., Bundesgesundheitsbericht/Federal Health Report). On the other hand, data stem from surveys which focus on the older population (cf. Table 1). These are either representative surveys focusing on the social situation of the elderly (e.g., Deutscher Alters-Survey/German Ageing

\footnotetext{
${ }^{2}$ For a discussion and comparative analysis of the data of the Eurobarometer [26] which covers 25 member states of the EU, see Hartmann-Tews [28].
}

Survey), surveys on health-related behavior and sport of the elderly (e.g., Bonner Alterssport-Studie/Study about sport of the elderly), or studies with a longitudinal perspective [e.g., The Interdisciplinary Longitudinal Study of Adult Development (ILSE)].

A comparison of these sets of data is a challenge as research designs and methods of the surveys vary a lot. Major problems in comparative analyses of surveys with respect to the question of participation in sports of the elderly can be identified in the following:

- Varying thematic cores of the surveys which may affect the answers on the questions on sport participation,

- The question of representativity of the data set (national, regional, selected age groups, gender, social class),

- Varying modes of questions and response categories, which bring about different results, e.g., with respect to the operationalization of participation in sports, and

- Different definitions and operationalizations of the focused analytical categories as there are age groups and social stratification.

In addition the publications cover a variety of thematic aspects and only a few focus systematically on social factors like gender, age, and social stratification and only some of them report statistical indicators of their computed data.

We will focus on empirical studies in Germany with data sets covering the last 20 years. The studies' representativeness ranges from the level of a municipality or a town until up to the national level. Most of them are cross-sectional data, and only very few are longitudinal data that are based on surveys with the same people at different times in order to allow for an analysis of life-course development of interests and behavior (cf. Table 1). For some subjects we will refer also to studies of the 1990s, when current data contain no information about the focused item.

\section{Sport participation rates of the elderly}

There have been several surveys in Germany over the past 20 years which present data concerning sport participation of elderly people. The main stock of surveys produces cross-sectional data, i.e., information on activities of different age groups at a certain point of time. A comparison of these surveys of the past decades can identify changes in the level of participation over a period of time and social trends in the development of the populations sport participation $[7,11,28,46]$.

All empirical studies document a negative relation between age and participation in sports [e.g., 7, 21, 23, 47]. Sports are predominantly leisure time activities of 
Table 1 Surveys reporting sport participation rates of elderly persons with respect to sociostructural categories

Study, date of survey(s)

A. General population surveys

Gesundheitsberichterstattung des Robert Koch-Instituts (Federal Health Reporting of Robert Koch-Institute), 1998-2009

Soziale Ungleichheit im Sport (Social Inequality in Sport), 2001

SOEP Sozioökonomisches Panel (SOEP Socio-economic Panel), 1985-2005

Sportverhaltensberichterstattung (Reports on sports behaviour), 2001

\section{B. Population studies of the elderly}

Deutscher Alters-Survey (German

Ageing Survey), 1996

ILSE-Interdisziplinäre Längsschnittstudie des Erwachsenenalters (Interdisciplinary Longitudinal Study of Adult

Development); 1994/1995, 1998/1999

Bonner Alterssport-Studie (Study about Sport of the Elderly, Bonn), 1996

"Seniorensport in Ostdeutschland" (Sport of the Elderly in East Germany), 1993

Kölner Studie Sport im Alter (Cologne Study Sport of the Elderly), 2006/2007

"Ein aktives Leben leben" ("Living an active Life"), 2006

Sport im Lebensverlauf (Sport during Lifecourse), 2008

getABI-German epidemiological trial on Ankle Brachial Index; 2001, 2006

Publications

Design, sample, representativeness

Becker and Schneider [7], Boerschel [9], Lampert et al. [42], Mensink [46], Robert Koch-Institut [50], Rütten et al. [52]

Nagel [47]

Breuer [10], Breuer [11], Breuer [12], Becker et al. [6], Combrink et al. [16], Klein and Becker [40]

Breuer and Rittner [14]

Kohli et al. [41]

Eichberg and Rott [22], Vogt and Köpsel [57]

Denk and Pache [18], Denk and Pache [19], Pache [48]

Baur et al. [3]

Combrink et al. [16], Hartmann-Tews and Tischer [31], Hartmann-Tews et al. [32], Hartmann-Tews [29], Tischer and Hartmann-Tews [56], Volkmann [58]

Becker et al. [4], Becker and ZimmermannStenzel [8], Huy and Thiel [36], Klein [39], Thiel et al. [55], Thiel et al. [54]

Engel and Nagel [24]

Hinrichs et al. [34]
Cross-sectional/part of it longitudinal

$N \sim 8,300$

Representative for Germany

Cross-sectional

$N=2,582$

Representative for Germany

Longitudinal

$N \sim 9,000-23,000$ per wave

Representative for Germany

Cross-sectional

$N=5,778$

Representative for Rhein-Sieg-Kreis

$N=3,023$

Representative for Essen

Cross-sectional and longitudinal

$N=4,838$

Representative for Germany

Longitudinal

$N=486$

Representative for Germany

$N=436$ (follow-up)

Not representative

Cross-sectional

$N=867$

Not representative

Cross-sectional

$N=548$

Representative for Brandenburg

Cross-sectional and retrospective data

$N=559$

Representative for Cologne

Cross-sectional and retrospective data

$N=2,002$

Representative for Baden-Wuertemberg Retrospective/longitudinal $N=1,739$

Representative for Chemnitz and Braunschweig

Cohort study/follow-up

$N=1,376$ (follow-up)

Representativity not documented children and adolescents and systematically decrease across the age groups: Older people show lower participation rates than the younger ones. It is important to note that this finding does not describe the individual development during life time, as a description of this kind can only be derived from longitudinal data (see following section). However, the findings show that at a defined reference time, the percentage of people taking part in sports is significantly higher in the younger age groups than in the older ones [e.g., 11, 23]. 
Sportification has taken place through a long period of time in the 1970s, 1980s, and 1990s. However, at the beginning of $1990 \mathrm{~s}$, statistics document a significant increase in participation of all people and the $40+$ groups in particular $[5,22]$. Social change and the involved sportification of society obviously had a stronger effect on adults and elderly people than it had on the younger age groups [42]. This in turn explains the finding that the general age group effect has become smaller over the past decades [29].

The participation rates documented in the surveys on people $50+$ vary between $30 \%$ and $60 \%[4,11,22,23,31$, 48]. Striking is the fact that the participation rates reported in surveys which focus on health and sports are generally much higher than participation rates in surveys which cover more general topics and in which sports is only a minor issue. The socioeconomic panel reports participation rates of the elderly ${ }^{3}$ ranging between $32 \%$ (55-64 years old) and $12 \%$ (75+ years old) [11], compared to the rates ranging between $63 \%$ (50-59 years old) to $32 \%$ ( $70+$ years old) which are reported in the health-focused study of the German Health Report [23]. ${ }^{4}$

The academic literature on participation in sports has often identified the so-called gender gap, i.e., the fact that less girls and women are participating in sports and that they are involved less regularly than boys and men [7]. Recent studies document a more ambiguous picture of gender differences in general and specifically with respect to the elderly. While some studies identify no significant gender difference in participation rates in sports of the elderly $[4,18,30,32,57]$, other studies show a significantly higher participation rate either of men in some of the age groups $50+[7,34,45]$ or of women $50+[11,50]$. There is only one common feature concerning gender differences across these diverse studies: within the highest age groups $(80+)$, women are strongly underrepresented. This result seems to be more based on a cohort effect than an age effect, as the socialization in physical education and sport of the now 80+ old women took place in masculine culture of sport and at a time when girls and women were excluded from many sports and society was rather reluctant towards sports activity of girls and women.

With respect to the frequency and intensity of sport activities, findings on gender differences are diverse as well. Some document that regular activity is more common among elderly women than men (50 to 70 years of age) [48]. Others document a tendency that men's (65+) activities are more frequent resp. that their amount of time spent doing sport is higher [23].

\footnotetext{
${ }^{3}$ Regular participation in sport of at least $1 \mathrm{~h}$ a week.

${ }^{4}$ Regular participation in sport- no lower time limit.
}

The diminishing or blurring gender gap in participation is due to the development of the past decades. The general increase of people participating in sports is mainly caused by an increase in number of girls and women in all age groups: their participation rates have increased significantly more than that of the boys and men [6, 7, 11, 29, 42]. Focusing the development between 1985 and 2005, the socioeconomic panel identifies the strongest increase of men's participation rates in the age group 45 to 54 with $15.5 \%$. The strongest increase of females' participation was $22.4 \%$ and relates to two age groups: the 45 to 54 and 55 to 64 years old [21].

General population surveys unanimously indicate a correlation between social class (resp. single indicators of social stratification, i.e., educational level, professional status, income/means) and participation in sports: The higher the social strata, the more people are involved in sports $[6,43]$. Especially educational level influences sport participation. These findings are in accordance with participation profiles of elderly people, i.e., a significant correlation between social class and sport participation of the elderly is confirmed [4, 16, 34, 42].

Only few studies concerning sport of the elderly examine interaction effects of gender and social class. However, the effect of social class in general seems to be more prominent with respect to older women than with respect to older men. Some surveys show that either educational level or social class effects sport participation of women stronger or more systematic $[16,42,48]$ than it does for men. In addition, there are no data that document an opposite finding.

\section{Sport from a life course perspective}

Most of the surveys produce cross-sectional data and inform about the amount of people participating in sports at a defined point of time or period of time. Very few surveys pursue a longitudinal research design.

The main source for longitudinal data of sport participation is the German SOEP, a representative longitudinal study of private households. It is the only data set providing information about sport participation through long-term, nonretrospective methods as it is based on a sample of identical persons since $1984 .^{5}$ Although a variety of research groups make use of this data set, there is no coordinated strategy to analyze it, which leads to numerous interpretations of the data. Information about changes in health behavior and participation in sport can be derived

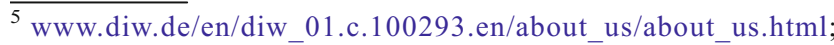
23.08.02010
} 
from the health surveys of the Robert Koch Institute which allow life-course analysis as well [42]. In addition the Interdisciplinary Longitudinal Study of Adult Development (ILSE) includes data about sport of elderly people, based on a sample of two cohorts (years of birth 1930-1932 and 1950-1952) that were interviewed and tested physically in a 4-year interval [22].

In essence the publications document two findings which are contradictory at first sight. On the one hand, the surveys indicate a high stability of some participation profiles across the life course, and on the other hand, they document a high variability of sport participation across the lifespan.

Continuity and stability in participation can be identified insofar as a majority of cases document either a continuously and long-lasting sport participation or a long-lasting inactivity. With reference to the socioeconomic panel, more than $50 \%$ of the physically active individuals stayed active over a period of 15 years (1986-2001), and even $70 \%$ of the inactive people continuously avoided doing sports [40]. At the same time, there are many patterns of discontinuous participation: some people stop their regular sport activities at one point in time and resume those activities at a later point in their lives. Another pattern is characterized by people with a long-lasting inactivity profile who become physically active only in an advanced age [22]. ${ }^{6}$

There is only one significant general feature: the amount of inactive people as a whole is continuously growing with advancing age [5]. The results of cross-sectional studies and longitudinal studies therefore complement each other in this point. There is a high probability of formerly active people to exit or inactive people to stay inactive with advancing age (the so-called age effect). The age effect is significant even when the health status of the elderly people is controlled [25, 40]. This finding is important as it refutes traditional stereotypes that decreasing participation in sports is due to a deteriorating health status. It calls attention to a variety of further social circumstances which influence the decisions to be or to become physically active, as there are for example changing cultural values (ideal of fitness), social norms (lifestyle elements), and individual resources (time and financial capital). Therefore, the tendency of an age effect does not reflect an outstanding trend of an increasing disengagement of sport across the life course, it rather masks the diversity of discontinuous participation. At the same time, effects of cohort affiliation on inactivity patterns are prominent, and for regular participation, effects of period like fitness fashions, etc. are also important [11].

The traditional proposition of a continuous disengagement of elderly people seems to be more prominent with

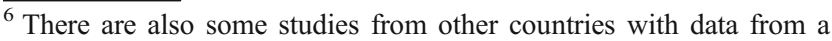
life course perspective $[17,35,51]$.
}

respect to men than with women. Changes in participation in sports of men are predominantly explained by the "advancing age," whereas changes in participation patterns of women can be far better explained by effects of cohort and/or effects of social and cultural influences at a given time [11]. A retrospective longitudinal study including about 1,700 elderly people $(50+)$ identified gender differences as well [24]. The number of elderly people who did not participate in sports for a long period of time (35 years) is significantly higher with respect to women than with respect to men. In addition, the probability of women $40+$ to start to participate in sport activities (again) is higher and vice versa the probability to exit is lower in comparison to men $(40+)$.

With respect to the potential influence of socioeconomic variables like income, educational level, and occupational status, only a minor stock of research is documented. On the basis of the data of ILSE, the authors identify education and income as important factors to influence continuity of sport while gender and age show no discriminating effect [22]. Findings from a study with a retrospective research design support these results. Higher education correlates positively with continuous sports activity, and cultural capital seems to be more important than economic capital $[4,39]$.

\section{Motivation for doing sports}

Data on elderly people's attitudes towards sports and on motivations to participate in sports are as heterogeneous as data on participation. Reasons are found in different research designs in general and different conceptualizations of "attitudes," "motives," and "motivation" in particular. Looking through the academic literature, two findings can be summarized.

Firstly, cross-sectional data document a dominance of health-related and fun-related complexes of motivation across all age groups with a tendency that the fun factor is less prominent in older age groups. With regard to further components of motivation (i.e. social issues/sociability, recreation, achievement), the findings about their ranking across the age groups vary a lot and are sometimes even contradictory [3, 15, 26, 44, 48].

Secondly, there are as may gender differences as there are gender similarities of elderly people with respect to attitudes, interests, and motivations to participate in sport. Various studies confirm that attitudes and motives along the dimension of health and fun are unanimously shared by elderly women and men. Traditional propositions on gender difference in motivational patterns in general and among elderly people in particular are still on the agenda, but the results are not at all uniform. Findings of studies conducted 
in the 1990s indicated that elderly men more often articulate "achievement" as one of their motives than elderly women [1, 3, 18, 19, 37, 53]. A more recent study does not confirm this finding: instead, when describing motivation to participate in sports, elderly women aged 55 to 75 agreed more on "experiencing achievements" than men [32]. Some studies document a stronger motivation of women to participate in sports in order to gain a better appearance and attractiveness [53] and other studies do not confirm this proposition [3, 18]. Furthermore some studies document a stronger motivation of (elderly) women to participate in sport for social reasons $[32,53]$ while other studies do not confirm this proposition [3, 18].

Two more recent studies on health behavior and sport of the elderly add interesting findings to the diverse stock of knowledge. Elderly women take significant more emphasis on the "anti-ageing" functions of sports than elderly men. Women rate higher on items concerning sports in order to prevent frailty, to train flexibility, to test performance, and to stay independent of care in the long term [32]. With regard to health behavior, more women than men are characterized by being "fit and performance hungry" than by being "conventional" and "easy going and committed" [36].

\section{Types of sport and sport settings}

Only few surveys gather information about preferred types of sports and the respective settings, and the nationwide surveys SOEP and RKI Health Surveys give no information about it. Cross-sectional surveys indicate that the types of sports which are chosen vary across the age groups. There seems to be a tendency to adapt sport activities to (a declining) physical fitness with advancing age. Whereas adults in their $30 \mathrm{~s}$ and $40 \mathrm{~s}$ prefer individual sports like jogging and fitness sports, the elderly prefer activities that can easily be integrated in daily life (e.g. walking and cycling). In addition nordic walking, swimming, gymnastics, and moderate hiking are preferred by people $50+$ [e.g., $3,13,14,33,38,48,49]$.

The most types of sport that elderly people do show no significant differences in the participation rates. Alongside with this general tendency, there are some types of sport preferred by one gender across all age groups. Among the elderly men prefer jogging and cycling and women prefer all kinds of gymnastics including aerobic and aqua-fitness $[3,18]$. Moreover, there is a tendency in sports clubs that male-dominated groups focus on traditional games while female-dominated groups are involved in various activities including movements to foster endurance and strength [2].

This gender profile can partly be explained by gendered connotations of sports. There are still stereotypes about the appropriateness of different types of sport to men and to women, e.g., gymnastics is seen as "adequate" and typical for women while team sports (esp. soccer) are seen as being more adequate for men. These stereotypes and connotations of sports are a social framework which influences the decisions to take part in the existing offers of sports clubs and other institutions. They may have an effect as a symbolic barrier, as elderly men in particular do not want to act like females [31]. It is interesting to note that imported movements like Tai Chi or Yoga, which originally do not have a gendered participation profile, are stereotyped as female sports as well.

The preferred settings of sports vary across the age groups. Adolescents and young adults primarily participate in activities of sports clubs whereas middle-aged people and elderly prefer an informal organizational frame. About two third of physically active older people organize their sports without any institutional frame. Sports clubs rank second and commercial organizations rank third in this list of settings $[1,3,18]$. About $13 \%$ of the elderly $(55+)$ are enrolled as a member of a sports club, and there are significantly more men than women [41]. This gendered profile of club membership is a characteristic feature of all ages. Retrospective longitudinal data support these findings as elderly men are far more often long-standing members of sports cubs than elderly women [24]. In contrast commercially run organizations and public offers are more often chosen by elderly women.

\section{Conclusions: what we know and what we do not know}

Focusing on participation in sports, the academic literature documents some patterns along the sociostructural variables of gender, age, and social class in the academic literature. On this basis a more or less sound stock of knowledge can be summarized:

- The increase of participation in sports over the past decades has been stronger with respect to elderly people $(45+)$ than with respect to children, youth, and young adults.

- Across all age groups, the increase in participation rates has been stronger for girls and women than for boys and men. Against this background the traditional gender gap in participation is diminishing or even reversing. Only within the age group $80+$, the traditional gender gap is still prominent.

- All empirical cross-sectional studies document a relation between age group and participation in sports: the older the group, the lower participation rates are.

- There is a general effect of social stratification on participation rates. This general effect is stronger with 
respect to elderly women than with respect to men, i.e., elderly women of lower social classes are the least physically active group in this age group and elderly women of higher social classes are the most active ones.

- Social stratification has also an effect on participation of the elderly in a life-course perspective. Higher education correlates positively with more continuous sports activity, and cultural capital seems to be more important than economic capital.

- Surveys indicate a high stability of participation profiles across life course (activity profile on the one hand and inactivity profile on the other hand). At the same time, they document a high variability of participation courses across the lifespan.

- On the basis of longitudinal surveys, it can be concluded that age is an influencing factor of participation in sports, but it is far less prominent than it was in the past (and less important as often suggested in the public and academic interpretations of participation rates). The age effect is significant even when the health status of the elderly people is controlled. At a closer look it seems to be of significant relevance only with respect to elderly men.

- A healthy lifestyle is the most often referred motivational dimension of adults and elderly people. The dimension of fun and joy is far less prominent for elderly people than for youth and young adults.

- The choice of sports is adapted to the physical fitness with advancing age, which means a decrease of preferences for games and an increase in preferences for sports with moderate performance (i.e., hiking, cycling, all sorts of gymnastics).

- Sports of the elderly in general is not gendered, because most types of sport are done by men and women likewise, but some types of sports have a strong gendered profile. Most notable is a gender pattern in activities referred to gymnastics: these activities are preferred by elderly women and strongly connoted as typical female (and as such not appropriate for men)

At the same time, we have to realize that the elderly population is not a homogeneous group as often suggested. On the contrary, elderly people (as other age groups) are characterized by diversity not only with respect to educational level, professional status, and income/capital and means but also with respect to health status, personality traits, resources of time, social integration, and many more aspects. Against this background there are a variety of blind spots in the stock of research. In particular we do know very little about the lifestyle and participation in sport of elderly people with migration background and of persons
80 years and above. As elderly people $80+$ are the fastest growing group of the population, it seems to be of special interest to invest in their needs and potentials to be involved in sport-related physical activity programs.

The review also reveals a lack of studies that:

- provide an interdisciplinary research design including sociological, psychological, and medical aspects as have been done in ILSE,

- compare and validate self-reported data on the basis of additional data sources (e.g., pedometer), and

- are based on a commonly shared and consistent operationalization of the methods which are used in surveys on sport activity in general and on sport of the elderly in particular.

\section{References}

1. Agricola S (1998) Senioren und Freizeit. Aktuelle Daten und Fakten zur Altersfreizeit. Eigenverlag, Erkrath

2. Allmer H, Tokarski W, Walschek R (2000) Bewegung, Spiel und Sport im Alter: Ein Handbuch zur Planung und Organisation attraktiver Angebote. Schriftenreihe des Bundesministeriums für Familie, Senioren, Frauen, Jugend (1. Auflage). Kohlhammer, Stuttgart

3. Baur J, Koch U, Krüger D, Quilitz T, Ruge T, Telschow S (1996) Seniorensport in Ostdeutschland. Zwischen Powersport und Kaffeeklatsch (Bd. 1). Meyer und Meyer, Aachen

4. Becker S, Huy C, Brinkhoff K-P, Gomolinsky U, Klein T, Thiel A, Zimmermann-Stenzel M (2007) Ein aktives Leben leben-Sport, Bewegung und Gesundheit im mittleren und höheren Erwachsenenalter. Konzeption, Datenerhebung und erste Ergebnisse eines repräsentativen Basis-Survey für die 50-70-jährige badenwürttembergische Wohnbevölkerung. Gesundheitswesen 69:401407

5. Becker S, Klein T (2007) Altern und Sport—zur Veränderung der sportlichen Aktivität im Lebenslauf. In: Wahl HW, Mollenkopf H (eds) Alternsforschung am Beginn des 21. Jahrhunderts, Berlin, AKA, pp 287-305

6. Becker S, Klein T, Schneider S (2006) Sportaktivität in Deutschland im 10-Jahres-Vergleich: Veränderungen und soziale Unterschiede. Deutsche Zeitschrift für Sportmedizin 57(9):226-232

7. Becker S, Schneider S (2005) Analysen zur Sportbeteiligung auf der Basis des repräsentativen Bundes-Gesundheitssurveys 1998. Sport und Gesellschaft 2(2):173-204

8. Becker S, Zimmermann-Stenzel M (2009) Sind Bewegungsmuffel auch Sportmuffel? Sport, Übergewicht und körperliche Mobilität in der Gruppe der 50- bis 70-jährigen baden-württembergischen Bevölkerung. Z Gerontol Geriatr 42(1):20-27

9. Boerschel J (2009) Geschlechtsspezifisches Gesundheitsverhalten im höheren Alter: Analysiert anhand des Gesundheitssurveys des RobertKoch-Instituts aus dem Jahre 2003. Diplomarbeit, DSHS Köln

10. Breuer C (2002) Sozialer Wandel und Sportengagement im Lebenslauf. In: Allmer H (ed) Sportengagement im Lebenslauf. Academia, St. Augustin, pp 61-82

11. Breuer C (2003) Entwicklung und Stabilität sportlicher Aktivität im Lebensverlauf. Zur Rolle von Alters-, Periode- und Kohorteneffekten. Sportwissenschaft 33(3):263-279

12. Breuer C (2004) Zur Dynamik der Sportnachfrage im Lebenslauf. Sport und Gesellschaft 1(1):50-72 
13. Breuer C (2005) Zur Entwicklung des Sportmarkts in einer alternden Gesellschaft. In: Horch HD, Hovemann G, Kaiser S, Viebahn K (eds) Perspektiven des Sportmarketing - Besonderheiten, Herausforderungen, Tendenzen (Beiträge des 4. Deutschen Sportökonomie-Kongresses vom 2-4.12.2004 in Köln). Lindner, Mainz, pp 29-41

14. Breuer C, Rittner V (2002) Berichterstattung und Wissensmanagement im Sportsystem. Konzeption einer Sportverhaltensberichterstattung für das Land Nordrhein-Westfalen. Sport und Buch Strauß, Köln

15. Breuer C, Wicker P (2007) Körperliche Aktivität über die Lebensspanne. In: Fuchs R, Göhner W (eds) Aufbau eines körperlich-aktiven Lebensstils. Hogrefe, Göttingen, pp 89-107

16. Combrink C, Hartmann-Tews I, Tischer U (2007) Social stratification in physical activity and sport of elderly people. ISSA World Congress, Copenhagen

17. Curtis J, White P, McPherson B (2000) Age and physical activity among Canadian women and men: findings from Longitudinal National Survey Data. J Aging Phys Activ 8:1-19

18. Denk H, Pache D (1996) Bewegung, Spiel und Sport im Alter. Bedürfnissituation Älterer. Band 1. Sport Buch Strauß, Köln

19. Denk H, Pache D (1999) Die Bonner Alterssport-Studie. Eine Untersuchung der Motivation und Einstellung Älterer zu Sportund Bewegungsaktivitäten. Sportwissenschaft 29(3):324-343

20. Digel H (1990) Die Versportlichung unserer Kultur und deren Folgen für den Sport-ein Beitrag zur Uneigentlichkeit des Sports. In: Gabler H, Göhner U (eds) Für einen besseren Sport. Hofmann, Schorndorf, pp 73-96

21. Deutsches Institut für Wirtschaftsforschung (2007) Daten des Sozio-ökonomischen Panels (SOEP) der Wellen x-y. Berlin

22. Eichberg S, Rott C (2004) Sportverhalten im mittleren und höheren Erwachsenenalter. Bedingungsfaktoren für Kontinuität und Diskontinuität. J Pub Health 12(2):93-104

23. Ellert U, Wirtz J, Ziese T (2006) Telefonischer Gesundheitssurvey des Robert-Koch-Instituts (2. Welle) (Beiträge zur Gesundheitsberichterstattung des Bundes). RKI, Berlin

24. Engel C, Nagel S (2011) Sport treiben ein Leben lang?Sportpartizipation im Lebensverlauf unter Berücksichtigung geschlechtsspezifischer Unterschiede. In: Hartmann-Tews, Dahmen B (eds) Geschlechterrelevanz in bewegungs- und gesundheitsorientierter Forschung. Beiträge aus dem Symposium ,Gender and Health in Motion-Gesundheit, Bewegung und Geschlecht aus interdisziplinärer Perspektive', Brennpunkte der Sportwissenschaft. Academia, St. Augustin

25. Erlinghagen M (2003) Wer treibt Sport im geteilten Deutschland? Graue Reihe des Instituts Arbeit und Technik 2003-04, Gelsenkirchen. http://www.iatge.de/aktuell/veroeff/2003/gr2003-04.pdf. Accessed 10 Nov 2010

26. European Commission (2004) Special Eurobarometer 213: The Citizens of the European Union and Sport (Fieldwork 10/11-2004; Wave 62.0 by Taylor Nelson Sofres \& EOS Gallup Europe) http:// ec.europa.eu/public_opinion/archives/ebs/ebs_213_report_en.pdf. Accessed 16 Aug 2006

27. Hartmann-Tews I (1998) Sport für alle!? Strukturwandel europäischer Sportsysteme im Vergleich. Hofmann, Schorndorf

28. Hartmann-Tews I (2006) Social stratification in sport and sport policy in the European Union. European Journal for Sport and Society 3(2):109-124

29. Hartmann-Tews I (2008) Gesundheit und Sport im höheren Lebensalter - eine Frage des Geschlechts? In: Hartmann-Tews I, Combrink C (eds) Gesundheit, Bewegung und Geschlecht. Beiträge aus dem interdisziplinären Genderkompetenzzentrum in den Sportwissenschaften, Brennpunkte der Sportwissenschaft (Bd. 30). Academica, St. Augustin, pp 97-116

30. Hartmann-Tews I, Combrink C, Tischer U (2007) Konstruktion von Geschlecht und Alter im Sport. In: Hartmann-Tews I, Dahmen
B (eds) Sportwissenschaftliche Geschlechterforschung zwischen Theorie Politik und Praxis. Czwalina, Hamburg, pp 49-58

31. Hartmann Tews I, Tischer U (2008) Alter(n) und sportliche Aktivität-auf den Spuren sozialer Deutungsmuster im höheren Lebensalter. Spectrum der Sportwissenschaften 2:39-58

32. Hartmann-Tews I, Tischer U, Combrink C (2008) Doing Gender und Doing Age im Kontext von Sport und Bewegung. Zeitschrift für Frauenforschung \& Geschlechterstudien 2:32-51

33. Heuwinkel D (1990) Sport für Ältere in einer sportaktiven alternden Gesellschaft. Z Gerontol Geriat 23(1):23-33

34. Hinrichs T, Trampisch U, Burghaus I, Endres HG, Klaaßen-Mielke R, Moschny A, Platen P (2010) Correlates of sport participation among community-dwelling elderly people in Germany: a cross-sectional study. Eur Rev Aging Phys A 7(2):105-115

35. Hirvensalo M, Lampinen P, Rantanen T (1998) Physical exercise in old age: an eight-year follow-up study on involvement, motives, and obstacles among persons age 65-84. J Aging Phys Activ 6:157-168

36. Huy C, Thiel A (2009) Altersbilder und Gesundheitsverhalten. Theorie und empirischer Befund zum Einfluss individueller Vorstellungen vom Alter(n) auf das Gesundheitsverhalten. Zeitschrift für Gesundheitspsychologie 17(3):121-132

37. Jansen R, Pache D, Vogt M (1999) Einstellungen von Älteren zum Sporttreiben im Alter: Ausgewählte Ergebnisse der ILSE-Studie im Ost-West-Vergleich. In: Lames M, Vogt M (eds) Bewegung, Spiel und Sport im Alter. Dokumentation eines Forschungskolloquiums des Instituts für Sportwissenschaft der Universität Rostock 5. März 1998. Universität Rostock, Rostock, pp 23-40

38. Kirschbaum B (2003) Sporttreiben und Sportverhalten in der Kommune-Möglichkeiten der empirischen Erfassung des lokalen Sportverhaltens als Basis kommunaler Sportstättenentwicklungsplanung (Schriften zur Körperkultur, Bd. 43). LitVerlag, Münster

39. Klein T (2009) Determinanten der Sportaktivität und der Sportart im Lebenslauf. Kölner Zeitschrift für Soziologie und Sozialpsychologie 61:1-32

40. Klein T, Becker S (2008) Gibt es wirklich eine Reduzierung sportlicher Aktivität im Lebenslauf? Eine Analyse alters- und kohortenbezogener Unterschiede der Sportaktivität. Z Soziol 37 (3):226-245

41. Kohli M, Künemund H, Motel A, Szydilk M (2000) Grunddaten zur Lebenssituation der 40-85jährigen deutschen Bevölkerung Ergebnisse der Alterssurvey. Weißensee, Berlin

42. Lampert T, Mensink GBM, Ziese T (2005) Sport und Gesundheit bei Erwachsenen in Deutschland. Bundesgesundheitsblatt-Gesundheitsforschung-Gesundheitsschutz 48 (12):1357-1364

43. Lamprecht M, Stamm H (1995) Soziale Differenzierung und soziale Ungleichheit im Breiten- und Freizeitsport. Sportwissenschaft 25(3):370-387

44. Lamprecht M, Stamm H (2001) Sport in der zweiten Lebenshälfte. Analysen zum Seniorensport in der Schweiz. L\&S Sozialforschung und Beratung AG, Zürich

45. Mensink G (2002) Körperliches Aktivitätsverhalten in Deutschland. In: Samitz G, Mensink G (eds) Körperliche Aktivität in Prävention und Therapie. Hans Marseille Verlag GmbH, München, pp 35-44

46. Mensink G (2003) Bundes-Gesundheitssurvey: Körperliche Aktivität. Aktive Freizeitgestaltung in Deutschland. Robert KochInstitut, Berlin

47. Nagel M (2003) Soziale Ungleichheit im Sport. Meyer and Meyer, Aachen

48. Pache D (2003) Die gegenwärtige Situation des Sports der Älteren. In: Denk H, Pache D, Schaller HJ (eds) Handbuch Alterssport. Hofmann, Schorndorf, pp 67-75 
49. Puhe H, Ossyssek F, Leisner C (2005) Sportverhalten in Deutschland 2005. SOKO Institut, Bielefeld

50. Robert Koch-Institut (2010) Daten und Fakten: Ergebnisse der Studie»Gesundheit in Deutsch-land aktuell 2009«. http://www.rki.de/ cln 169/nn 205760/DE/Content/GBE/gbe node.html? nnn=true. Accessed $1 \overline{7}$ Nov 2010

51. Ruchlin H, Lachs M (1999) Prevalence and correlates of exercise among older adults. J Appl Gerontol 18:341-357

52. Rütten A, Abu-Omar K, Lampert T, Ziese T (2005) Körperliche Aktivität. Robert Koch-Institut, Berlin

53. Schick G (1998) Motivation Älterer zu Bewegungs- und Sportaktivitäten. Sportwissenschaft 28:195-212

54. Thiel A, Gomolinsky U, Huy C (2009) Altersstereotype und Sportaktivität in der Generation 50+. Z Gerontol Geriatr 42:145154
55. Thiel A, Huy C, Gomolinsky U (2008) Alterssport in BadenWüttemberg-Präferenzen, Motive und Settings für die Sportaktivität in der Generation 50+. Deutsche Zeitschrift für Sportmedizin 59(7-8):163-167

56. Tischer U, Hartmann-Tews I (2009) Die Sportaktivität älterer Männer aus soziologischer Perspektive. Blickpunkt der MannWissenschaftliches Journal für Männergesundheit 7(3):20-25

57. Vogt M, Köpsel J (2000) Freizeitverhalten und körperliche Leistungsfähigkeit im Alter. In: Martin P, Martin M, Schmitt M, Sperling U (eds) Interdisziplinäre Längsschnittstudie des Erwachsenenalters (ILSE). Abschlussbericht über den 2. Untersuchungsdurchgang. Universität Heidelberg

58. Volkmann M (2010) Sportaktivität und Einstellungen zu Sport und Gesundheit im höheren Alter: Eine Sekundäranalyse. Diplomarbeit, DSHS Köln 